\title{
Online shopping behaviour of college students
}

\begin{abstract}
Internet users in India have been increasing day by day. In 2014 there were about 243 million internet users. The main reasons for the high usage were affordable price of smart phones and internet tariff plans. Due to these reasons people started moving online for purchase of products and services. E-commerce is growing by 38 per cent per year. The total value of E-commerce was INR 90,000 crores during 2014. It was predicted that it will be about INR six lakh crores in next five years. It has been reported that about 70 per cent of internet users and the online shoppers were youth. Hence, a study was conducted to assess the internet usage behaviour of youth and factors that influenced them to shop online. The study was carried out with a sample size of 120 students from different colleges in Coimbatore, Tamil $\mathrm{Nadu}$. About 80 per cent of them were using smart phones and all were using internet daily. Young female students were spent more money for online shopping than young male students. Main factors that influenced them to shop online were informed choice, loyalty, competitive pricing, accessibility, convenience, security issues, knowledge and window shopping.
\end{abstract}

KEY WORDS : E-commerce, Social media marketing, Accessibility

How to cite this paper : Balaji, P. (2015). Online shopping behaviour of college students. Internat. J. Com. \& Bus. Manage, 8(1) : 84-87.

\section{AUTHOR FOR CORRESPONDENCE}

P. BALAJI, Department of Agricultural and Rural Management, Tamil Nadu Agricultural University, COIMBATORE (T.N.) INDIA

Email: pbalaji@tnau.ac.in 